\title{
PENGEMBANGAN BUSANA FANTASI DENGAN SUMBER IDE BUSANA TRADISIONAL DAYAK
}

\author{
Kadek Onny Swastini, I Gede Sudirtha, Ketut Widiartini \\ Program Studi Pendidikan Kesejahteraan Keluarga, Fakultas Teknik dan Kejuruan \\ Universitas Pendidikan Ganesha \\ Singaraja, Indonesia \\ e-mail: kadekonnyswastini@gmail.com gede.sudirtha@undiksha.ac.id. \\ ketut.widiartini@undiksha.ac.id.
}

\begin{abstract}
Abstrak
Penelitian ini bertujuan untuk mendeskripsikan hasil pengembangan busana fantasi dengan sumber ide busana tradisional Dayak. Jenis penelitian yang digunakan adalah penelitian pengembangan (Research and Development) dengan model pengembangan ADDIE yang terdiri dari 5 tahap, yaitu : analisis, (analyze), desain (design), pegembangan (development), implementasi (implementation), dan evaluasi (evaluation). Metode pengumpulan data dalam penelitian ini dilakukan dengan penilaian instrumen pengembangan busana fantasi dengan sumber ide busana tradisional Dayak. Instrumen ini diuji oleh dua ahli isi, yang dihitung dengan rumus Gregory, sehingga validitas instrumen diperoleh sebesar 0,90 dengan kriteria validitas sangat tinggi sehingga dapat digunakan untuk uji produk. Hasil pengembangan busana fantasi terdiri dari 2 busana, yaitu busana fantasi dengan siluet $L$, dan busana fantasi dengan siluet $A$ yang bersumber ide busana tradisional Dayak. Hasil produk busana fantasi ini memiliki kualifikasi sangat baik dengan presentase $94,54 \%$ pada uji produk busana.
\end{abstract}

Kata Kunci : Busana Fantasi, Pengembangan, Sumber Ide

\begin{abstract}
The research aims is to describe the results of fantasy fashion development, which the ideas come from the traditional Dayak fashion. The type of this research is Research and Development and it is used the model of ADDIE development which consists of 5 stages, namely : analyze, design, development, implementation, and evaluation. The method of data collection in this study was carried out by assessing the instruments of fantasy fashion development with sources of Dayak tradisional fashion ideas. This instruments was tested by two content experts, which ware calculated by Gregory's formula, so the instruments validity was 0,90 with very high validity criteria so that it could be used for product testing. The results of the development of fantasy fashion consisted of 2 fashions, namely fashion fantasy with $L$ silhouette, and fantasy fashion with A silhouette sourced from traditional Dayak fashion ideas. The results of this fantasy fashion product have very good qualifications with a percentage is $94,54 \%$ in the fashion product test.
\end{abstract}

Key words : fantasy fashion, development, source of ideas. 
Jurnal Bosaparis: Pendidikan Kesejahteraan Keluarga

Volume 10, Nomor 2, Juli 2019

\section{PENDAHULUAN}

Indonesia terdiri dari beberapa pulau yang memiliki karakteristik tersendiri. Pulau-pulau yang tersebar di seluruh Nusantara ini dihuni berbagai suku bangsa yang memiliki budaya dan bahasa yang berbeda. Keanekaragaman budaya yang dimiliki oleh masing-masing suku (multi etnis) melahirkan satu budaya multi etnik dan inilah yang menjadi daya tarik bagi Indonesia dan sebagai salah satu ikon pariwisata. Salah satunya adalah busana daerah yang diciptakan oleh para penduduk/nenek moyang kita yang ternyata sampai saat ini masih tetap eksis meski dalam lingkungan yang terbatas (Erwin, 2014: 6). Setiap busana adat dari masing-masing provinsi mewakili nilai-nilai dan makna tertentu yang dianut oleh masyarakat setempat, sehingga hal ini dianggap mewakili 'budaya' dari wilayah itu sendiri (Reno, 2016: 2). Warisan budaya merupakan latar belakang masyarakat Indonesia yang tidak dapat diabaikan. Oleh karena itu, pengelolaan warisan budaya merupakan salah satu langkah yang perlu dilakukan (Puguh, 2015: 138). Salah satu warisan budaya Indonesia yaitu busana tradisional Dayak Kalimantan yang merupakan suatu tanda kebudayaan yang sangat bernilai dan dimiliki oleh sebagian besar suku Dayak asli Kalimantan (Jalung, 2015: 132)

Busana tradisional suku Dayak pada umumnya memiliki siluet $\mathrm{H}$ yang identik dengan baju atasan tanpa lengan atau berlengan maupun rompi yang dipadupadankan dengan rok dengan warna dasar hitam maupun merah serta motif berwarna kontras yaitu kuning, biru, merah, hijau, dan putih. Busana tradisional Dayak memiliki motif khas seperti motif pakis, motif butung enggang dan motif naga.

Motif pakis adalah motif yang paling sering ditemui karena selain umumnya diaplikasikan pada propertyproperti kesenian daerah, rumah adat suku dayak maupun pada busana tradisional suku dayak. Motif ini memiliki makna mengenai keabadian hidup. Penciptaan Motif ini terinspirasi dari tumbuhan Pakis (Polystichum setiferum) (Leonaldy, 2014 : 5).

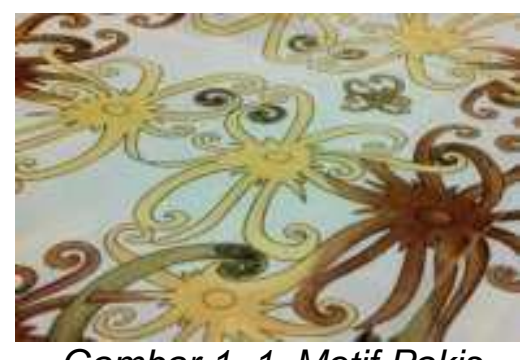

Gambar 1. 1. Motif Pakis

Sumber : Dragonohalim, 2014 
Motif burung enggang adalah moif yang sering digunakan dalam kegiatan seni suku Dayak. Burung enggang yang menjadi figur motif enggang adalah burung enggang gading (buceros/rhinoplax vigil) yang memiliki habitat di Semenanjung Malaya, Sumatera, dan Kalimantan. Sifat burung enggang ini yang sebagian dijadikan filosofi hidup oleh suku Dayak, dimana walaupun burung enggang memiliki tubuh yang besar, paruh dan bulu yang indah, namun terdapat jiwa pemberani, pekerja keras, rendah hati,dan setia. Konotasi ini berkembang menjadi lebih jauh menjadi mitos yang diyakini oleh suku Dayak dan menjadi salah satu dasar dari paham animisme. Mitos tersebut mengenai asalusul nenek moyangnya yang diyakini turun dari langit kemudian datang ke bumi dengan mengambil wujud burung enggang. Seperti motif binatang lainnya burung enggang adalah motif yang diistimewakan hanya boleh digunakan oleh kaum paren (raja dalam kalangan Dayak kenyah). Motif burung enggang dianggap sebagai simbol "Alam Atas" yaitu alam kedewataan bagi suku Dayak. Sedangkan motif naga dianggap sebagai penguasa alam bawah yang sering dikaitkan dengan sifat feminim, yang berkaitan dengan air, bulan, dan gelap. Motif naga merupakan representative hewan reptile berbadan ular yang tinggal di air dan memilki kesaktian, maka dari itu naga juga disebut sebagai ular naga (Marlina, $2016:$ 10)

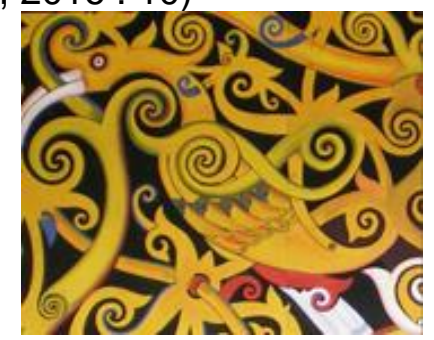

Gambar 1. 2. Motif Burung Enggang Sumber : Gita Hastarika, 2013

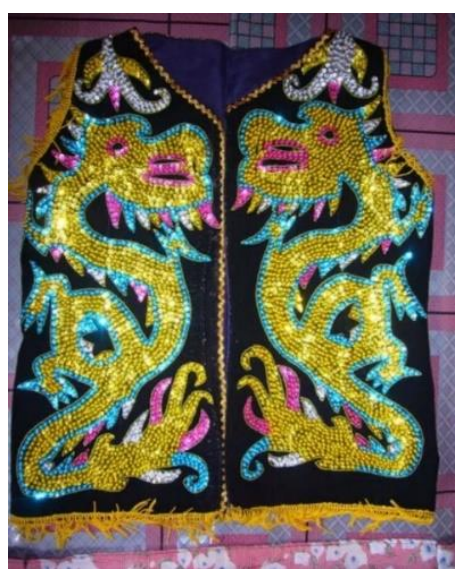

Gambar 1. 3. Motif Naga

Sumber : Sangiangdewata, 2015

Pada dasarnya masih banyak terdapat motif-motif hasil seni masyarakat suku Dayak yang pengaplikasiannya dapat ditemukan pada rumah-rumah adat, properti kesenian, ukiran tenun maupun pada busana tradisionalnya. Selain motifmotif yang digunakan pada busana tradisional tersebut, Suku Dayak juga banyak menggunakan aksesoris yang terbuat dari bulu burung enggang. Burung enggang atau rangkong dalam Bahasa inggris disebut hornbill karena paruhnya memiliki tanduk atau cula. Oleh masyarakat Dayak, enggang termasuk burung yang dikeramatkan. Burung yang termasuk dalam spesies yang dilindungi ini hampir tidak bisa dilepaskan dari kehidupan suku Dayak. Makna burung enggang bagi suku Dayak menjadi salah satu tanda kedekatan masyarakat Nusantara dengan alam sekitarnya. Masyarakat suku Dayak sangat menghormati burung enggang dan menganggapnya sebagai panglima burung. Hampir semua bagian tubuh burung enggang menjadi lambang dan symbol kebesaran dan kemuliaan suku Dayak. Sayapnya yang tebal menggambarkan pemimpin yang melindungi rakyatnya. Suaranya yang keras menyimbolkan perintah pemimpin yang selalu di dengar oleh rakyat. Ekornya yang panjang menjadi tanda kemakmuran rakyatnya. Secara keseluruhan, burung enggang menyimbolkan watak seorang pemimpin yang dicintai rakyatnya. Bulu ekor enggang memiliki warna hitam dan putih 
digunakan dalam pakaian adat Kalimantan dan digunakan sebagai kostum tari-tarian saat upacara adat. Para penari adat menggunakan bulu enggang sebagai hiasan kepala dan jari-jari tangan.

Dari uraian di atas, dapat disimpulkan bahwa busana tradisional Dayak Kalimantan merupakan busana yang dihiasi dengan motif pakis, motif burung enggang, dan motif naga dengan aksesoris berupa bulu burung enggang. Busana tradisional Dayak merupakan salah satu warisan budaya Indonesia yang tidak dapat diabaikan. Namun, dalam era modernisasi sekarang ini, tidak sedikit penduduk Indonesia yang menganut budaya asing dan melupakan budaya sendiri (Prayitno, 2015: 1). Menurut Puguh (2015 : 138) Bangsa Indonesia tidak dapat hanya kembali ke zaman lampau. Namun demikian, warisan budaya merupakan latar belakang masyarakat Indonesia yang tidak dapat diabaikan. Oleh karena itu, pengelolaan warisan budaya merupakan salah satu langkah yang perlu dilakukan. Salah satunya busana tradisional Dayak ini perlu dikelola yaitu dengan cara menggunakannya sebagai sumber ide dalam pengemangan busana fantasi. Peneliti mengembangkan busana fantasi dikarenakan busana fantasi merupakan busana yang dibuat sebagai hasil daya cipta, khayalan atau angan-angan, gagasan, ide atau inspirasi seseorang yang bentuk busana nya menyerupai benda aslinya serta menitikberatkan fungsi estetis atau fungsi keindahan dari pada fungsi pakai. Maka, dalam pembuatannya dapat diterapkan berbagai garniture atau hiasan busana, sehingga busana ini dapat dibuat dengan kreativitas yang tinggi. Serta sebagai desainer baru, peneliti perlu mengembangkan busana fantasi agar karya tersebut dapat ditonjolkan pada acara peragaan busana yang bertujuan untuk melahirkan desainer-desainer baru yang mampu melihat dan menyikapi setiap perubahan yang terjadi pada dunia mode.

Peneliti menggunakan sumber ide busana tradisional Dayak Kalimantan dikarenakan busana tradisional dayak ini memiliki motif yang eksotik. Motif eksotik menurut kamus besar Bahasa Indonesia, berarti memiliki daya Tarik khas, luar biasa, istimewa, aneh dan ganjil. Motif ini sudah terkenal dalam masyarakat internasional dengan adanya pagelaran seni tari tradisional Dayak Kenyah seperti Tari Enggang dan Tari Mandau dimana para penarinya menggunakan pakaian adat lengkap dengan segala atributnya. Serta motif khas suku Dayak Kalimantan ini semakin dikenal ketika memenangkan gelar sebagai kostum nasional terbaik di ajang kontes kecantikan Miss Supranational tahun 2014 mengalahkan 70 kandidat dari negara lain (Malina, 2016: 2). Berikut ini busana yang digunakan oleh Miss Supranational tahun 2014.

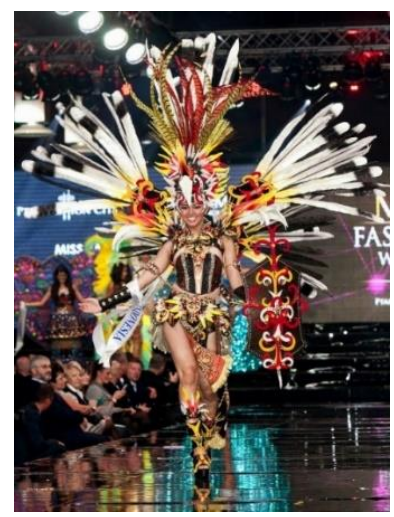

Gambar 1. 4. Busana Miss Supranational Tahun 2014

Sumber : Bakanekobaka, 2015

Dari adanya hal tersebut, peneliti mengembangkan busana fantasi dengan sumber ide busana tradisional Dayak Kalimantan dengan tujuan pariwisata yaitu untuk memperkenalkan busana fantasi yang bersumber ide dari busana tradisional Dayak kepada masyarakat luas maupun wisatawan dalam acara pagelaran busana. Dalam busana fantasi yang dikembangkan ini, peneliti memilih untuk menggunakan motif pakis dari berbagai motif yang diuraikan di atas, karena selain paling sering digunakan dalam busana tradisional suku Dayak, motif ini juga mudah ditemui di pasaran dengan kisaran harga yang cukup terjangkau. 


\section{Karena busana yang} dikembangkan adalah busana fantasi maka sumber idenya tidak hanya pada busana tradisional dayak, bentuk dari busana tersebut mengambil sumber ide dari busana trend 2018. Peneliti menggunakan siluet busana yang trend pada tahun 2018 karena sesuai dengan pernyataan Prayitno (2015: 1) yang mengatakan bahwa dalam era modernisasi sekarang ini, tidak sedikit penduduk Indonesia yang menganut budaya asing dan melupakan budaya sendiri, serta pernyataan Puguh (2015: 138) yang mengatakan bahwa Bangsa Indonesia tidak dapat hanya kembali ke zaman lampau. Trend mode yang selalu berkembang menjadi pemicu gaya hidup masyarakat dalam hal busana (Boedijono, 2014 : 4). Maka dari itu peneliti ingin menggunakan siluet busana yang trend pada tahun 2018 yang diperpadukan dengan sumber ide busana tradisional Dayak. Busana ini nantinya diharapkan dapat menampilkan sebuah busana fantasi yang trendy namun tetap memiliki ciri khas dari busana tradisional Dayak.

Berdasarkan latar belakang yang telah dipaparkan tersebut, perlu adanya penelitian untuk masalah tersebut dengan mengambil judul : Pengembangan Busana Fantasi Dengan Sumber Ide Busana Tradisional Dayak.

\section{METODE PENELITIAN}

Metode yang digunakan dalam penelitian ini adalah penelitian pengembangan. Model pengembangan yang digunakan pada penelitian ini adalah pengembangan model ADDIE. Model pengembangan ADDIE merupakan model pengembangan yang bertujuan untuk mengembangkan suatu produk baru, atau menyempurnakan produk yang telah ada dan hasilnya dapat dipertanggungjawabkan.

Model pengembangan ADDIE ini dapat memberikan peluang untuk melakukan evaluasi terhadap setiap tahap. Hal ini dapat memberikan dampak positif terhadap pengembangan kualitas produk pengembangan. Dampak positif yang ditimbulkan tersebut adalah meminimalisir tingkat kesalahan atau kekurangan produk pada tahap akhir model ini.

Desain penelitian pengembangan model ADDIE yang meliputi 5 tahapan yaitu :

Tahap pertama yaitu tahap analisis. Pada tahapan ini peneliti menganalisis sumber ide dari busana fantasi yaitu busana tradisional Dayak Kalimantan. Pada tahap ini peneliti menganalisis motif, warna dan aksesoris busana tradisional Dayak. Motif yang akan digunakan dalam penelitian ini adalah motif pakis, warna dari busana tradisional Dayak yang akan digunakan dalam penelitian ini yaitu merah, biru, dan kuning, serta aksesoris yang akan digunakan dalam penelitian ini merupakan aksesoris dengan bentuk bulu burung enggang dengan warna putih dan hitam.

Tahap yang kedua yaitu tahap perancangan. Pada tahap ini peneliti membuat desain busana fantasi yang akan dikembangkan menjadi sebuah produk berupa busana fantasi dengan sumber ide busana tradisional Dayak. Desain busana yang akan dikembangkan yaitu menggunakan siluet $L$ dan siluet $A$ dengan menggunakan bahan bermotif pakis dengan warna biru, serta bahan lain dengan warna merah dan kuning. Aksesoris pada desain ini dibuat menyerupai bentuk bulu burung enggang pada mahkota, hiasan pada pinggang, dan sayap.

Tahap yang ketiga yaitu tahap pengembangan. Pada tahap ini meliputi proses dari pembuatan busana fantasi itu sendiri. Proses pembuatan busana fantasi melalui tiga tahap yaitu persiapan yang pengambilan ukuran, pembuatan pola, serta merancang bahan dan harga. Selanjutnya pelaksanaan yang meliputi peletakkan pola pada bahan, pemotongan, dan pemberian tanda jahitan, penjelujuran, dan penyambungan, evaluasi proses I, penjahitan dan evaluasi tahap II. Evaluasi tahap II ini dilakukan dengan tujuan untuk mengetahui tingkat keberhasilan dari hasil busana fantasi dengan sumber ide busana tradisional Dayak. 


\begin{abstract}
Tahap yang keempat yaitu implementasi. Pada tahap ini implementasi dilakukan pada uji coba instrument dan uji coba produk. Sebelum melakukan uji coba produk, peneliti terlebih dahulu melakukan uji coba instrument. Hal ini bertujuan untuk mengetahui apakah instrument yang dibuat valid atau tidak sehingga nantinya akan mendapat data yang akurat dan dapat dipertanggungjawabkan.

Sedangkan untuk uji coba produk bertujuan untuk melihat hasil dari busana fantasi yang telah dikembangkan sesuai dengan sumber ide yaitu busana tradisional Dayak.
\end{abstract}

\begin{tabular}{|c|c|}
\hline $\begin{array}{c}\text { Tingkat } \\
\text { Pencapaian }\end{array}$ & Kulaifikasi \\
\hline $90 \%-100 \%$ & Sangat Baik \\
\hline $75 \%-89 \%$ & Baik \\
\hline $65 \%-74 \%$ & Cukup Baik \\
\hline $55 \%-64 \%$ & Kurang \\
\hline $0 \%-54 \%$ & Sangat Kurang \\
\hline
\end{tabular}

Tahap yang terakhir adalah evaluasi. Kegiatan evaluasi dilakukan setelah semua tahapan selesai. Tujuan dari evaluasi adalah untuk mengetahui pengembangan produk berupa busana fantasi yang telah dibuat sesuai dengan sumber ide yaitu busana tradisional Dayak. Subyek uji coba dari penelitian ini merupakan 2 orang ahli produk busana. Uji coba dilakukan terhadap hasil produk pengembangan berupa busana fantasi dengan sumber ide busana tradisional Dayak.

Dalam penelitian ini instrument pengumpulan data yang digunakan adalah kuisioner. Kuisioner atau angket merupakan teknik pengumpulan data yang dilakukan dengan memberi seperangkat pertanyaan tertulis kepada responden untuk dijawab (Sugiyono,2009:199). Instrumen kuisioner pada penelitian pengembangan ini digunakan untuk memperoleh data dari ahli busana sebagai bahan evaluasi produk yang dikembangkan. Sebelum instrument kuisioner ini dapat dipergunakan, instrument ini dianalisis validitas isi oleh 2 judges ahli isi, yang dihitung dengan rumus Gregory, sehingga validitas instrumen diperolh sebesar 0,90 dengan kriteria validitas sangat tinggi sehingga dapat digunakan untuk uji produk.

Dalam penelitian ini menggunakan teknik analisis deskriptif kuantitatif dan deskriptif kualitatif.Teknik analisis deskriptif kuantitatif digunakan untuk mengolah data yang diperoleh melalui angket uji produk dalam bentuk deskriptif presentase. Rumus yang digunakan untuk menghitung presentase dari masingmasing subyek adalah sebagai berikut :

$$
N=\frac{\text { skor perolehan }}{\text { skor maksimal }} \times 100 \%
$$

Selanjutnya, untuk menghitung presentase keseluruhan subjek digunakan rumus sebagai berikut :

Table 3.7

Konversi Tingkat Pencapaian

(sumber : Tegeh,dkk,2014)

Data dalam penelititian kualitatif bersifat deskritif bukan angka. Data dapat berupa gejala-gejala, kejadian dan peristiwa kemudian dianalisis dalam bentuk kategori-kategori. Menurut Agung (2012:67) "Analisis deskritif kualitatif yaitu suatu cara analisis/pengolahan data dengan jalan menyusun secara sistematis dalam bentuk kalimat/ kata-kata, kategorikategori mengenai suatu objek (benda, gejala, variabel tertentu), sehingga akhirnya diperoleh simpulan umum".

Teknik analisis deskriptif kualitatif ini digunakan untuk mengolah data hasil uji produk ahli busana. Teknik analisis data ini dilakukan dengan mengelompokkan informasi-informasi dari data kualitatif yang berupa masukan, tanggapan, kritik dan saran perbaikan yang terdapat pada angket.

\section{HASIL DAN PEMBAHASAN}

Untuk memperoleh hasil pengembangan busana fantasi dengan sumber ide busana tradisional Dayak ini menggunakan model pengembangan ADDIE yang terdiri dari 5 tahap, yaitu : Pada tahap pertama yaitu analisis, yang peneliti lakukan dalam 
pengembangan busana fantasi ini adalah menganalisis dari sumber ide busana fantasi yang dikembangkan. Sumber ide yang dijadikan acuan dalam pengembangan busana fantasi ini adalah busana tradisional Dayak serta sumber ide lainnya yaitu trend 2018. Dari sumber ide tersebut dikembangkan unsur-unsur, prinsip-prinsip dan karakteristik dari busana tradisional Dayak serta trend 2018 yang digunakan untuk mengembangkan busana fantasi dalam penelitian ini.

Pada tahap yang kedua yaitu desain ini yang peneliti lakukan adalah mendesain busana fantasi yang akan dikembangkan. Setelah melakukan analyze, maka peneliti mendesain model busana fantasi sesuai dengan sumber ide busana tradisional Dayak serta sumber ide lain yaitu trend 2018 sesuai dengan analysis yang dijelaskan.

Setelah tahap kedua (design) selesai, selanjutnya dilakukan tahap ketiga yaitu development atau pengembangan. Pada tahap ini meliputi proses pembuatan busana fantasi dengan sumber ide busana tradisional Dayak. Pada proses ini meliputi 3 tahapan yaitu persiapan, pelaksanaan dan evaluasi. Pada tahap persiapan, penulis menyiapkan gambar kerja, pengambilan ukuran yang diperlukan untuk membuat busana fantasi, pembuatan pola kecil, pembuatan rancangan bahan dan harga yang digunakan untuk mengetahui penghabisan bahan dan harga dari bahan yang diperlukan serta pola besar busana fantasi. Kemudian dilanjutkan dengan tahap pelaksanaan yang meliputi meletakkan pola diatas bahan disesuaikan dengan arah serat, memotong bahan, menjelujur bagian-bagian potongan kain untuk membuat busana fantasi. Setelah penjelujuran selesai dilanjutkan dengan evaluasi 1, pada proses ini busana digunakan oleh 2 orang model kemudian dicek apakah busana tersebut sudah pas dan sesuai dengan desain busana fantasi yang dibuat. Kemudian dilanjutkan dengan proses menjahit secara permanen bagian-bagian dari busana fantasi. Setelah proses menjahit selesai dilanjutkan dengan evaluasi 2, evaluasi ini dilakukan setelah proses menjahit dan finishing selesai. Tujuan dari evaluasi 2 ini adalah untuk mengecek hasil dari busana fantasi apakah busana dan kelengkapan yang dibuat sesuai dengan desain busana yang dibuat. Pada tahap ini peneliti melakukan pengecekan secara keseluruhan terhadap hasil busana fantasi dengan sumber ide busana tradisional Dayak yang bertujuan untuk mengetahui sejauh mana keberhasilan dari tahan persiapan dan pelaksanaan dalam pengembangan busana fantasi. Evaluasi ini meliputi keseluruhan bagian-bagian busana termasuk segala aksesoris pada busana fantasi.

Setelah melakukan tahap development atau pengembangan busana fantasi dengan sumber ide busana tradisional Dayak, kemudian dilanjutkan dengan tahap implementasi yang dilakukan dengan uji ahli produk. Untuk uji produk, peneliti melibatkan 2 ahli produk busana yaitu ibu Ria Yunita yang merupakan pemilik dari butik ria, dan ibu Luh Nusari S.Pd yang merupakan guru dari SMK Negeri 2 Singaraja. Berdasarkan hasil uji produk pengembangan busana fantasi dengan sumber ide busana tradisional Dayak memiliki kualifikasi sangat baik dengan tingkat pencapaian $94,54 \%$.

Tahap terakhir yang dilakukan adalah tahap evaluasi yang dilakukan dalam penelitian pengembangan ini adalah evaluasi secara formatif. Tujuan dari evaluasi ini adalah memperbaiki busana fantasi yang telah dikembangkan. Evaluasi dilakukan untuk perbaikanperbaikan sesuai dengan penilaian dan masukan yang diberikan oleh ahli busana. Pada tahapan ini, peneliti melakukan evaluasi menurut hasil penilaian dari ahli busana dan memperbaiki busana fantasi sesuai dengan masukan dan saran yang diberikan oleh ahli busana.

Berikut ini hasil dari pengembangan busana fantasi dengan sumber ide busana tradisional Dayak.

Gambar 1. Hasil Akhir Busana Fantasi dengan Siluet $A$ 


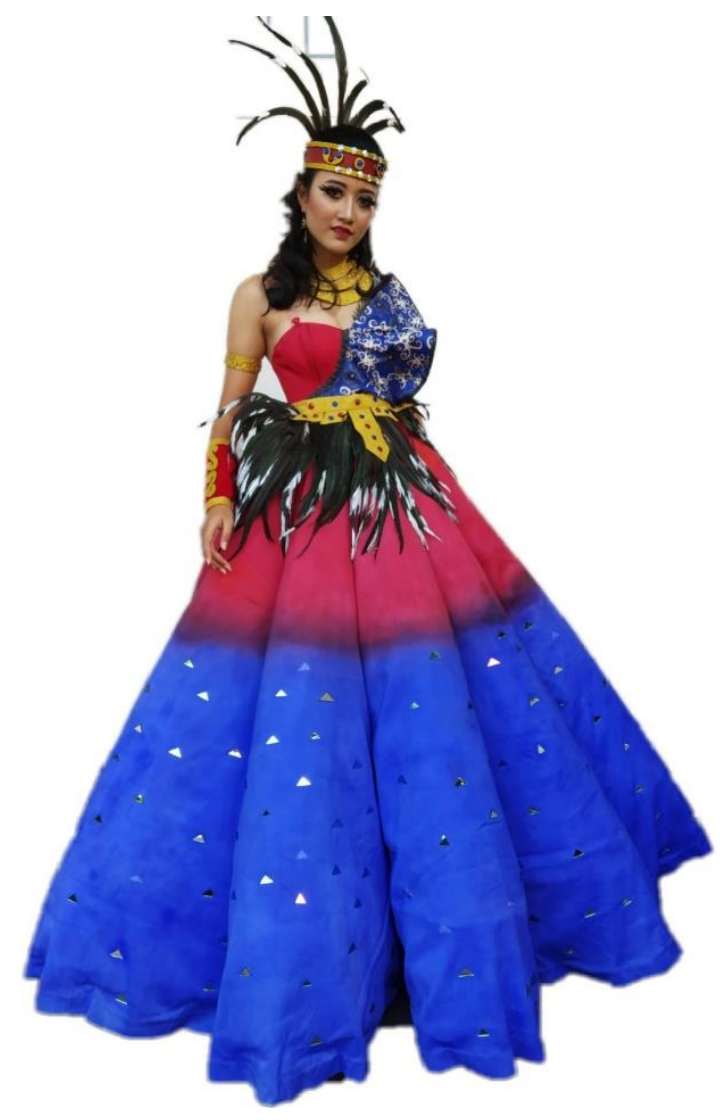

Gambar 2. Hasil Busana Fantasi dengan Siluet L

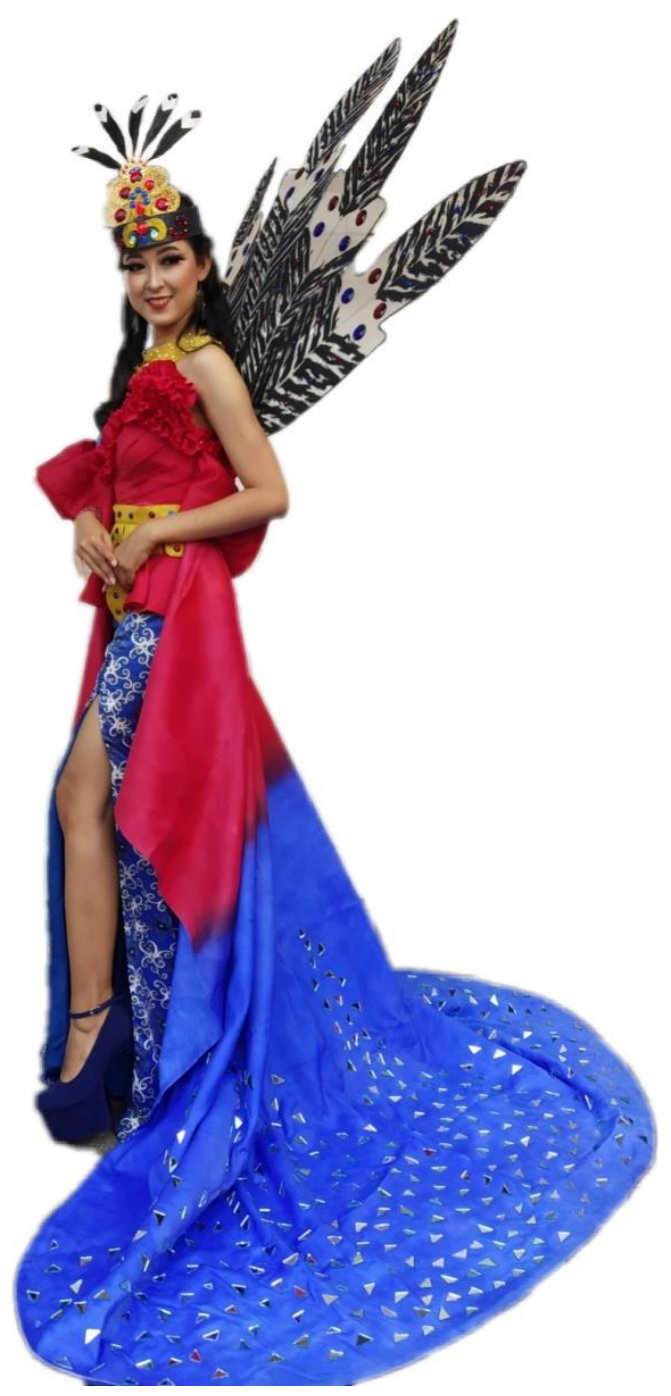

PEMBAHASAN

Pengembangan produk berupa busana fantasi dengan sumber ide busana tradisional Dayak menciptakan sebuah produk dengan ide yang baru. Hal ini sesuai dengan pernyataan Sri Widarwati (1996:58) yang menyatakan "Sumber ide adalah suatu hal yang dapat menimbulkan seseorang untuk menciptakan suatu ide baru."

Busana fantasi yang dikembangkan ini sesuai dengan sumber ide yang digunakan yaitu busana tradisional Dayak karena pada busana yang telah dikembangkan ini menggunakan motif pakis khas Dayak, Hal ini sesuai dengan penelitian yang dilakukan oleh Leonaldy pada tahun 2015 dengan judul "Motif Dayak" dalam penelitian ini menyebutkan bahwa ada 
beberapa motif yang menghiasi busana tradisional Dayak yaitu salah satunya motif pakis yang merupakan motif yang paling sering ditemui karena diaplikasikan pada properti-properti kesenian daerah, rumah adat suku Dayak maupun pada busana tradisional suku Dayak.

Warna yang digunakan merupakan warna-warna yang kontras seperti merah, biru, dan kuning serta penggunaan hiasan bulu burung enggang. Hal ini sesuai dengan penelitian Herlina Marlina pada tahun 2016 yang menyatakan bahwa busana tradisional Dayak yang berwarnawarni tidak hanya berfungsi sebagai penambah keindahan saja, namun juga memiliki arti seperti warna kuning yang merupakan simbol dari sebuah keagungan dan kesakralan. Putih yang menjadi wujud dari kesucian dan keyakinan terhadap sang pencipta. Merah sebagai warna yang menggambarkan semangat hidup yang menyala, serta biru yang harapan akan sumber kekuatan yang tidak pernah habis. Selain itu, burung enggang juga memiliki makna yang diyakini suku Dayak yaitu burung enggang dianggap sebagai simbol "Alam Atas" yaitu alam kedewataan bagi suku Dayak.

Aksesoris dari busana fantasi dengan sumber ide busana tradisional Dayak ini menggunakan aksesoris berupa hiasan kepala, hiasan pinggang dan sayap yang menggunakan hiasan bulu burung enggang, serta aksesoris lain seperti kalung dan gelang sebagai pelengkap dari busana fantasi. Hal ini sesuai dengan Ernawati (2008) yang menyatakan bahwa aksesoris merupakan pelengkap busana yang sifatnya hanya untuk menambah keindahan pemakai busana tersebut.

Pengembangan busana fantasi dengan sumber ide busana tradisional dayak ini menggunakan siluet trend busana 2018 ini merupakan suatu pengembangan busana fantasi yang trendy namun tetap memiliki ciri khas dari busana tradisional Dayak. Hal ini sesuai dengan pernyataan Prayitno (2015:1) yang mengatakan bahwa dalam era modernisasi sekarang ini, tidak sedikit penduduk Indonesia yang menganut budaya asing dan melupakan budaya sendiri, serta pernyataan Puguh (2015: 138) yang mengatakan bahwa Bangsa Indonesia tidak dapat hanya kembali ke zaman lampau. Trend mode yang selalu berkembang menjadi pemicu gaya hidup masyarakat dalam hal busana (Boedijono, 2014 : 4). Busana fantasi yang dikembangkan ini menggunakan siluet $A$ dan siluet $L$.

\section{SIMPULAN}

Proses pengembangan busana
fantasi dengan sumber ide busana tradisional dayak ini menggunakan langkah-langkah pengembangan model ADDIE yaitu analysze, design, development, implementation, evaluation.

Pada tahap analisis, peneliti menganalisis sumber ide busana tradisional Dayak serta sumber lain yaitu busana trend 2018, kemudian dilanjutkan dengan tahap design, peneliti membuat desain sesuai dengan analisis yang dilakukan. Pada tahap selanjutnya yaitu development, dilakukan tahap pengembangan yang terdiri dari 3 proses yaitu persiapan (pengambilan ukuran, pembuatan pola kecil, pembuatan rancangan bahan dan harga, serta pembuatan pola besar), pelaksanaan (pemotongan bahan, penjelujuran, evaluasi 1, tahap menjahit, serta finishing), dan evaluasi. Selanjutnya dilakukan tahap implementation yang dilakukan oleh 3 orang ahli busana. Lalu tahap terakhir yaitu evaluation yang dilakukan dengan melakukan evaluasi terhadap hasil pengembangan busana fantasi dengan sumber ide busana tradisional Dayak. Hasil evaluasi ini nantinya akan dapat dipergunakan sebagai acuan dalam pengembangan produk yang serupa

Hasil pengembangan busana fantasi dengan sumber ide busana tradisional dayak ini memiliki kualifikasi sangat baik dengan presentasi 94,54\% berdasarkan penilaian ahli busana.

\section{SARAN}


Berdasarkan hasil yang diperoleh dari penelitian ini bahwa pengembangan busana fantasi dengan sumber ide busana tradisional Dayak mendapatkan penilaian dengan kualifikasi sangat baik dari penilaian ahli busana. Sehingga bisa dijadikan sebagai acuan bagi pengembangan busana fantasi selanjutnya dengan mengambil sumber ide yang sama.

\section{DAFTAR RUJUKAN}

Bakanekobaka. 2015. Best National Costume : Indonesia. Januari 30. Accessed Juni 25, 2019. http://ericopieter.blogspot.com/201 5/01/best-national-costumeindonesia. html?m=1.

Boedijono, Yogi. 2014. Panduan Lengkap Menjahit. Jakarta Selatan: PT Kawan Pustaka.

Dragonohalim. 2014. Kalimantan Punya. Oktober 29. Accessed Juni 25, 2019.

https://linimasa.com/2014/10/29/ka limantan-punya/.

Ernawati. 2008. Tata Busana Untuk SMK Jilid 2. Jakarta: Direktorat Jenderal Manajemen Pendidikan Sekolah Menengah, Departemen Pendidikan Nasional.

Erwin, Lily T. 2014. Jilbab Etnik Dari Kain Nusantara. Jakarta: PT Gramedia Pustaka Utama.

Jalung, Melkias. 2015. "Analisis Semiotika Pakaian Adat Dayak Bahau Sebagai Alat Komunikasi Budaya Dalam Berinteraksi Dengan Masyarakat." eJournal IImu Komunikasi Vol 3 No. 42015 Fakultas IImu Sosial dan Politik Universitas Mulawarman.

Leonaldy. 2015. "Motif Dayak." Jurnal Pendidikan dan Pembelajaran Vol 4, No 9 (2015) Fakultas Keguruan dan IImu Pendidikan Universitas Tanjungpura Pontianak.
Malina, Herlinda. 2016. "Kajian Semiotik Motif Pakaian Adat Suku Dayak Kenyah Di Desa Pampang Samarinda Kalimantan Timur." Jurnal Institutional Respository Institut Seni Indonesia Yogyakarta.

Prayitno, Rudi. 2015. "Desain Multimedia Interaktif Terhadap Pengenalan Budaya Di Indonesia." Jurnal Repository Muhammadiyah University of Ponorogo.

Puguh, Dhanang Respati, and dkk. 2009. "Laporan Akhir Naskah Akademik Tentang Pelestarian, Pengembangan, dan pemanfaatan seni dan upacara tradisi di kota semarang." Dinas Kebudayaan dan pariwisata kota semarang.

Reno, Tjhan. 2016. "Perancangan Karya Fotografi Fashion Tentang Busana Adat Nusantara Dengan Tema "Bhineka Tuggal Ika"." Jurnal Desain Komunikasi Visual Adiwarna Universitas Kristen Petra.

Sangiangdewata. 2015. Mengenal Berbagai Macam Motif Lukis Suku Dayak. Juli 15. Accessed Juni 25, 2019.

https://m.kaskus.co.id/thread/55a6 80a2c0cb1700768b4567/mengena I-berbagai-macam-motif-seni-lukissuku-dayak/.

Sugiyono. 2014. Metode Penelitian Kuantitatif, Kualitatif dan $R \& B$. Jakarta: Alfabeta.

Tegeh, I Made, and dkk. 2014. Model Penelitian Pengembangan. Singaraja: Graha IImu.

Widarwati, Sri, and dkk. 1996. Desain Busana II. Yogyakarta: Media FPTK IKIP Yogyakarta. 